\title{
Phytoplankton growth conditions during autumn and winter in the Irminger Sea, North Atlantic
}

\author{
Ben A. Ward ${ }^{1, *}$, Joanna J. Waniek ${ }^{2}$ \\ ${ }^{1}$ National Oceanography Centre, Southampton, School of Ocean and Earth Science, University of Southampton, \\ Waterfront Campus, European Way, Southampton SO14 3ZH, UK \\ ${ }^{2}$ Institut für Ostseeforschung Warnemünde, Seestraße 15, 18119 Rostock, Germany
}

\begin{abstract}
Physical and chemical properties of the water column, along with meteorological conditions were examined for their relationship with phytoplankton biomass in the Irminger Sea during late autumn and early winter. Data were collected during 2 cruises to the region in November and December 2001 and November 2002. Phytoplankton biomass was approximated by (chl a) concentrations within the water column. When examined during autumn and winter alone, the Irminger Sea was suitably described as one biogeochemical region responding to varying meteorological forcing. Hydrographic differences within the region were not observed to have a significant effect on phytoplankton growth during this period. Strong correlations with latitude were seen in chl a concentrations, physical conditions (including mixed layer depth) and meteorological forcing (including net heat flux). Variability in autumn/winter phytoplankton growth conditions appears to be driven by light limitation modulated by meteorological forcing. The temporal and spatial scales of locations sampled in 2001 represent a progression in the physical and biological conditions from late autumn to early winter. Along this 'virtual transect', a baseline value of approximately $0.1 \mathrm{mg} \mathrm{m}^{-3}$ is seen in the mean chl a concentrations within the mixed layer. We postulate that convection provides a mechanism for reduction of net losses of phytoplankton, by helping to keep phytoplankton within the mixed layer. Under such conditions, a deeper and therefore more accurate estimation of the critical depth would be valid. Evidence of the extended maintenance of phytoplankton within the mixed layer is presented in the form of the relative dominances of different phytoplankton groups.
\end{abstract}

KEY WORDS: Phytoplankton · Winter production $\cdot$ Physical forcing $\cdot$ Light limitation $\cdot$ Meteorology Irminger Sea

\section{INTRODUCTION}

While physical, chemical and biological factors controlling spring and summer phytoplankton growth in the North Atlantic have been the subject of much research since the mid 20th century (e.g. Sverdrup 1953, Barton et al. 2003), autumn and winter cruises in this part of the Atlantic have been sparse as a result of the extremely inclement weather that often occurs at this time (Backhaus et al. 2003). Two such cruises were undertaken in the Irminger Sea as part of the Natural Environment Research Council (NERC), Marine Productivity Thematic Programme, and these are analysed here with a view to defining the physical and chemical controls of autumn and winter productivity in this region.

Physical processes in the ocean dictate where phytoplankton occur, and the conditions they experience there. This paper focuses on such processes occupying horizontal-spatial scales $\geq$ mesoscale, and temporal scales of weeks to months. Sverdrup's critical depth hypothesis states that net phytoplankton blooming will only occur when cells are trapped near the surface, where enough light is available to allow photosynthesis to compensate for loss processes, as long as nutrients are available (Sverdrup 1953). The depth at which daily depth-integrated loss processes first exceed daily depth-integrated production is labelled the 'critical 
depth'. When the mixed layer penetrates below this depth, net daily production within the mixed layer is, by definition, unable to sustain net growth of phytoplankton populations.

Over the entire North Atlantic subpolar gyre, winter mixed layer depths (MLD) are generally greater than most estimations of the critical depth which are usually calculated from levels of photosynthetically active radiation (PAR) (Dutkiewicz et al. 2001, Follows \& Dutkiewicz 2001, Siegel et al. 2002). According to the critical depth theory, loss processes within the mixed layer should exceed production, yet phytoplankton persist within the mixed layer throughout the winter in the region (Backhaus et al. 2003). In the present study, winter levels of chl $a$ in the Irminger Sea were investigated, and mechanisms allowing for maintenance of winter phytoplankton populations are discussed.

The presence of different water types, each characterised by variations in temperature, salinity and nutrient concentrations, can influence the magnitude and duration of spring phytoplankton blooms, either through variation in the nutrient concentrations between water masses (Gačić et al. 2002, Thomas et al. 2003), through variation in the propensity to stratification as a result of hydrography, or a combination of the two (Santoleri et al. 2003, Waniek 2003, Waniek et al. 2005, Holliday et al. 2006). Holliday et al. (2006) defined 7 different zones with distinct hydrographic properties seen during the Marine Productivity Programme, and analysed 6 in terms of stratification, nutrients and biological parameters within the context of the annual cycle. They presented a unique set of early winter observations in the context of the seasonal cycle, but pointed out that the surveys were conducted in late autumn, and thus do not provide a useful description of true winter conditions (Holliday et al. 2006).

In the present study, the water types proposed by Holliday et al. (2006) are used as a starting framework for the analysis of the cruise data. However, it will be shown that the hydrographic zone analysis is less useful in describing autumn/winter conditions in isolation, and that it is more useful to consider the data as varying continuously with the changing seasons and with latitude. Thus we present data in 3 ways: (1) according to the hydrographic zones defined by Holliday et al. (2006), (2) split between the 2 legs of Cruise D258 and (3) in relation to the latitude of sample stations. The aim of using this format is to assess the importance of latitudinal variability (and thus meteorological forcing) in comparison to hydrography within the context of this investigation. Finally, the Irminger Sea data will be analysed to find evidence of the winter baseline phytoplankton population, and the mechanisms by which the stock is maintained will be investigated.

\section{MATERIALS AND METHODS}

Study area. The Irminger Sea is located in the northern North Atlantic within the North Atlantic subpolar gyre (Longhurst et al. 1995). It is bordered by Greenland in the northwest and Iceland in the northeast. The Denmark Straight links the Irminger Sea with the Arctic Ocean, and Reykjanes Ridge, extending for approximately 750 miles southwest of Iceland, marks the boundary with the Iceland Basin to the east. The Labrador Sea marks the southwestern boundary between Cape Farewell and the tip of Reykjanes Ridge. Circulation within the basin is generally cyclonic (Lavender et al. 2000, Reverdin et al. 2003, Pollard et al. 2004). A branch of the Irminger Current heads north along the west side of Reykjanes Ridge, before retroflecting towards the southwest, south of Iceland. Here it merges with cold, dense northern overflows, before heading southwest in the relatively fresh East Greenland Current (Bacon 2002). The general cyclonic circulation leads to Ekman pumping across the base of the Ekman Layer; thus the water column may become preconditioned to convective overturning. It has been shown that strong meteorological forcing, particularly an orographically enhanced wind known as the 'Greenland Tip Jet', can cause deep convection in the Irminger Sea to depths of 2000 m (Pickart et al. 2002, Bacon et al. 2003, Moore 2003, Pickart et al. 2003). Convection to such depths is rare, but winter overturning within the region may often reach depths between 200 and $500 \mathrm{~m}$ (Pickart et al. 2003, Holliday et al. 2006). For a more detailed description of the hydrography of the region, particularly in relation to biology, the reader is referred to Holliday et al. (2006) and Read (2001).

Surveys and data. In situ data were collected as part of the NERC Marine Productivity Thematic Programme, itself part of the international Global Ocean Ecosystem Dynamics project (GLOBEC). Data presented here are from the 2 autumn/winter cruises of the RSS 'Discovery': November to December 2001 (D258) and November 2002 (D267). Surveys during D258 were collected over 2 legs, dated 1 to 22 November 2001 and 28 November to 12 December 2001 (Pollard \& Hay 2002). Data from D267 were collected between 15 and 25 November 2002.

CTD casts yielded data for pressure (dbar), in situ temperature $\left({ }^{\circ} \mathrm{C}\right)$, salinity, potential temperature $\left({ }^{\circ} \mathrm{C}\right)$ and density $\left(\mathrm{kg} \mathrm{m}^{-3}\right)$ with a vertical resolution of 2 dbar. Salinity data from the CTD were calibrated against discrete bottle samples to World Ocean Circulation Experiment (WOCE) standards $( \pm 0.002)$. Mixed layer depths were estimated from profiles of potential density using the algorithm described in appendix 1 of Thomson \& Fine (2003). This technique approximates the depth profile of potential density using a number of 
linearly connected breakpoints. An algorithm is used to adjust the position of the breakpoints along the depth profile such that an error threshold is not exceeded, whilst seeking the minimum number of breakpoints.
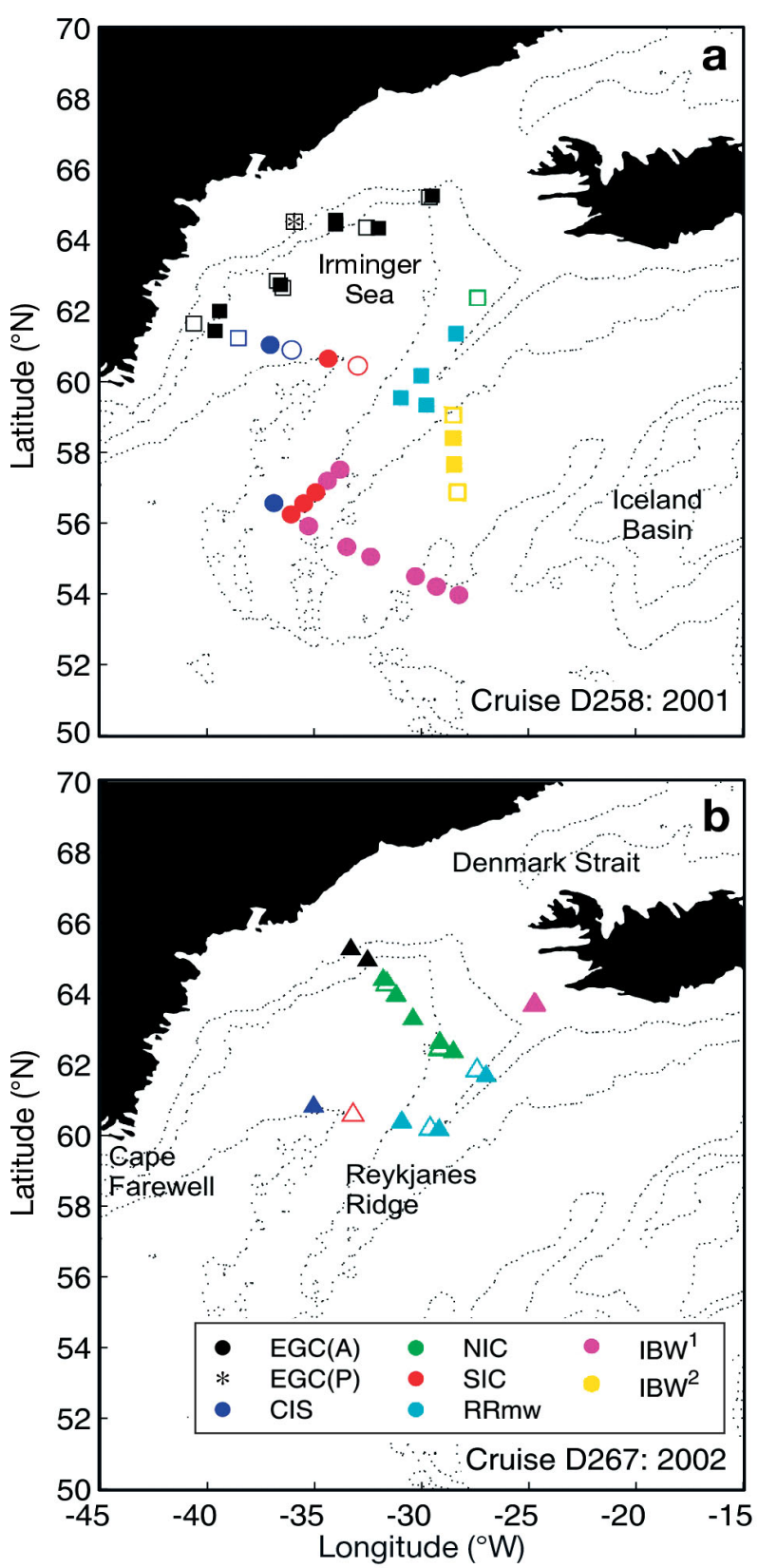

Fig. 1. Locations of the stations from (a) Cruise D258 and (b) Cruise D267. Circles: stations sampled during Leg 1 of D258; squares: stations sampled during Leg 2; triangles: all stations sampled during Cruise D267. Solid symbols: CTD casts; open symbols: towed CTD (ARIES, Auto recording instrument sampler) casts; $(*)$ the $\mathrm{EGC}(\mathrm{P})$ station was sampled by a towed CTD during Leg 2. Isobaths: 1000, 2000 and $3000 \mathrm{~m}$. Water masses - EGC(A) and (P): East Greenland Current (Atlantic and polar, respectively); CIS: central Irminger Sea; NIC and SIC: northern and southern Irminger Current, respectively; RRmw: Reykjanes Ridge mode water; IBW1 and IBW2: Iceland Basin water (Leg 1 and Leg 2, respectively)
The resultant profile has the top 3 breakpoints located at the surface, the estimated base of the mixed layer and the estimated base of the pycnocline, respectively. See Fig. 1 for the study area and location of CTD casts.

Meteorological and sea-surface parameters were measured underway from a shipboard instrument package throughout the cruise with a temporal resolution of $2 \mathrm{~min}$. The parameters recorded include: sea surface temperature $\left({ }^{\circ} \mathrm{C}\right)$, sea surface salinity, sea surface chl a concentration $\left(\mathrm{mg} \mathrm{m}^{-3}\right)$, air pressure (dbar), solar irradiance $\left(\mathrm{W} \mathrm{m}^{-2}\right)$, wind speed $\left(\mathrm{m} \mathrm{s}^{-1}\right)$, wind direction $\left({ }^{\circ}\right)$ and humidity $(\%)$. Hereafter, these parameters shall be referred to as 'underway data'. The underway data were linked to each sampled station by finding all values recorded within $0.01^{\circ}$ in each compass direction of the location, finding the median of all these data in time and calculating the mean from $12 \mathrm{~h}$ on either side of the median. In this way, underway data were acquired for approximately the same times and positions of the CTD casts.

The net heat flux at the surface boundary was calculated according to the parameters and formulae in table 2 of Waniek (2003), as the sum of the sensible and latent heat fluxes, longwave back-radiation and surface irradiance.

Discrete samples for nutrient and chl a analysis were collected from Niskin bottles on the CTD-Rosette system. All nutrient samples were collected in new $40 \mathrm{ml}$ vials and refrigerated at $4^{\circ} \mathrm{C}$ until analysis. Analysis of all samples took place within $12 \mathrm{~h}$ from the time of sampling (Sanders \& Jickels 2000). Concentrations of the dissolved inorganic nutrients nitrate and nitrite (hereafter collectively called nitrate), orthophosphate (hereafter phosphate) and silicate were measured on unfiltered water samples using a Scalar SanPlus segmented-flow autoanalyser based on the analytical methods of Kirkwood (1995). Throughout each sample run, wash and drift standards were run every 10 to 15 min to enable baseline and drift corrections. Nutrient concentrations were calculated using calibration curves obtained from dilution of the in-house standards, analysis of Ocean Scientific International (OSI) nutrient standards, and measurement of deep ocean bulk seawater standard. The precision of the nutrient measurements was estimated to be better than $\pm 0.18 \mu \mathrm{M}$ for nitrate and $\pm 0.15 \mu \mathrm{M}$ for silicate $(1 \%$ of standard nitrate and $0.5 \%$ for silicate).

CTD and shipboard (underway) fluorometer readings were converted to chl a concentrations by calibration against discrete bottle samples. Water samples were drawn into 51 carboys. For the chlorophyll analysis, two $200 \mathrm{ml}$ aliquots were filtered through Whatmann GF/F filters. The filters were placed in amber glass vials containing $90 \%$ acetone and stored in the dark for $24 \mathrm{~h}$ to extract chl $a$. Samples for $\mathrm{chl}$ a were warmed to room 
temperature before the fluorescence was measured using a Turner Design Fluorometer (TD700). Chlorophyll standard solutions (Sigma) were used for calibration of the fluorometer prior to analysis of each set of samples. The chl a concentrations were calculated from the absorbance measured at 750,664, 647 and $630 \mathrm{~nm}$ in a Cecil Spectrophotometer using the equations of Jeffrey \& Humprey (1975). The Sea-Bird calibration was used to convert the fluorometer readings in volts to nominal chl $a$ in $\mathrm{mg} \mathrm{m}^{-3}$. Calibration of the CTD fluorometer was performed by calculating a linear fit between the bottle samples and CTD fluorometer readings. The calibrations for all stations was as follows: chl $a=-0.028+$ $2.812 \times$ fluorometer value with $\mathrm{r}^{2}=0.96, \sigma=0.05$. The $\mathrm{SD}$ of the residuals after applying the calibration to the CTD fluorometer data was $0.2 \mathrm{mg} \mathrm{m}^{-3}$. The detection limit of this fluorometer was $0.01 \mathrm{mg} \mathrm{m}^{-3}$. According to Waniek et al. (2005) there was no bias due to photoinhibition in surface waters during daylight.

Phytoplankton samples were taken for laboratory microscopical identification at the surface, at the chlorophyll maximum and at $100 \mathrm{~m}$ depth. Upon analysis, total cell counts and carbon biomasses were yielded for diatoms, heterotrophic and photosynthetic dinoflagellates of approximately $20 \mu \mathrm{m}, 2$ and $4 \mu \mathrm{m}$ flagellates, picoplankton and ciliates. Duplicates of 100 ml samples at each depth were preserved with $1 \%$ Lugol solution and $2 \%$ buffered formalin. Taxa were enumerated using inverted microscopy. Counts for individual species were converted to volume measurements of cells (Kovala \& Larrance 1966) and then to cell carbon using the cell volume to carbon relationships given by Eppley et al. (1970), as described by Holligan et al. (1984). Picoplankton samples were preserved with glutaraldehyde and were enumerated with a LEICA DMIRB microscope at $\times 1000$ magnification. For further details, see Pollard \& Hay (2002).

Attenuation of light and critical depth. Surface irradiance data from shipboard underway measurements were converted to PAR using an empirical algorithm (Kirk 1994):

$$
\left(\mathrm{PAR}=0.49 \cdot I_{\text {surface }}\right.
$$

where $I_{\text {surface }}$ is the downwelling irradiance at sea surface, in $\mathrm{W} \mathrm{m}^{-2}$. As a first approximation, $Z_{\mathrm{e}}$ (depth at which the downwelling PAR is reduced to $1 \%$ of the surface value) was estimated using an empirical relationship between the mean concentration of chl $a$ in the euphotic layer, $C$, and the depth of the euphotic layer, $Z_{\mathrm{e}}$ (Morel 1988) such that:

$$
z^{-1} \int_{z}^{0} \mathrm{chl} \mathrm{d} z=C=4190 Z_{\mathrm{e}}^{-2.34}
$$

Eq. (2) was solved numerically for $Z_{\mathrm{e}}$ at each station using the distribution of chl $a$ within the surface layer and assuming case 1 (i.e. sediment free) water (Jerlov 1968). Given an approximation of the mean chl a concentration within the euphotic zone $(C)$, it is possible to derive spectral values of the light attenuation. Constants $K_{w}(\lambda), \chi_{c}(\lambda)$ and $e(\lambda)$ are given for wavelengths every $5 \mathrm{~nm}$ between 400 and $700 \mathrm{~nm}$ in Table 2 of Morel (1988). Combined with $C$ in the equation:

$$
\left(K(\lambda)=K_{w}(\lambda)+\chi_{c}(\lambda) C^{e(\lambda)}\right.
$$

a value of the attenuation coefficient $K(\lambda)$ can be derived for each $5 \mathrm{~nm}$ band in the given range. As the spectral composition of PAR was not available, the mean of $K(\lambda)$ was taken over the spectral range, yielding a value of $K$ that could be applied to the surface PAR data. Using this technique, an estimation of the downward flux of PAR was available at every depth from 0 to $500 \mathrm{~m}$ at all stations with irradiance and chl $a$ data. The attenuation coefficient for the irradiance was assumed to be the same as the attenuation coefficient for PAR, based on the fact that most radiation outside the PAR spectral range is attenuated in the upper metre of the water column (Sverdrup 1953).

The critical depth $\left(Z_{\mathrm{Cr}}\right)$ is defined by Siegel et al. (2002) after Sverdrup (1953) as the depth where depthintegrated, community loss processes balance depthintegrated production by photosynthesis. Community loss processes are defined as all processes that lead to loss of phytoplankton biomass from the mixed layer (e.g. respiration, mortality, sinking, grazing, etc.). Siegel et al. (2002) also defines the community compensation irradiance $\left(I_{c}\right)$ as the daily average irradiance within the mixed layer required for production to balance community loss processes, assigning a value of $\sim 3.9 \mathrm{~W} \mathrm{~m}^{-2}$ based on satellite observations and in situ measurements in the North Atlantic between 50 and $70^{\circ} \mathrm{N}$. In practice, this is an estimate of the amount of light required within the mixed layer for the initiation of a spring bloom under nutrient replete conditions. If the mean daily surface irradiance $\left(I_{0}\right)$ and the diffuse attenuation coefficient $(K)$ are known for each station, then they can be used in Eq. (4) to find an estimate of the critical depth (Siegel et al. 2002). Under conditions where light is sufficient for a bloom, this value should be greater than the MLD:

$$
\left(K Z_{\mathrm{Cr}}\right)^{-1}\left(1-\mathrm{e}^{-K Z_{\mathrm{Cr}}}\right)=I_{\mathrm{C}} I_{0}^{-1}
$$

Classification of hydrographic zones. Stations were grouped into 7 zones according to surface hydrographic properties after Holliday et al. (2006). These zones were named: East Greenland Current Atlantic and polar (EGC[A] and $[\mathrm{P}]$, respectively), Central Irminger Sea (CIS), Northern Irminger Current (NIC), Southern Irminger Current (SIC), Reykjanes Ridge mode water (RRmw) and Iceland Basin water type (IBwt). Further to the classification of Holliday et al. 
(2006), IBwt is subdivided into 2 groups (IBW ${ }_{1}$ and $\mathrm{IBW}_{2}$ ), according to whether they were visited during Leg 1 or Leg 2, respectively. Data were analysed with respect to these classifications. Further details may be found in Holliday et al. (2006).

Statistical analysis. Wherever sensible, comparison of 2 groups (e.g. the 2 cruise legs in D258) was done using Student's $t$-test; comparison of multiple groups (e.g. different zonal classifications) was done using ANOVA and Tukey tests. All tests were carried out to the $95 \%$ confidence level. When the data were not normally distributed, or data were incompatible as a result of nonhomogenous variances, statistical tests were not performed.

\section{RESULTS}

Initially, only Cruise D258 was analysed, as it provided a more extensive data set than Cruise D267. Cruise D267 is examined to verify patterns seen during D258, and the 2 cruises are briefly compared in terms of interannual variability.

\section{Mixed layer depths}

Mixed layer depths (MLD) from Cruise D258 were analysed individually by station (Fig. $2 \mathrm{a}-\mathrm{C}$ ), according to the zonal classifications described in the Materials and Methods (Fig. 2d-f), and according to cruise Legs (1 and 2) (Fig. 2g-i). It should be noted that zones CIS, SIC and IBW I $_{1}$ were sampled at 17 stations, 16 of which were sampled during Leg 1. Conversely, zones EGC(A) and EGC(P), NIC, RRmw and $\mathrm{IBW}_{2}$ were sampled entirely during Leg 2, at 21 stations. Hereafter, these 2 groups will be referred to as Leg 1 zones and Leg 2 zones.

Analysis of the MLD from each zone reveals that each of the Leg 1 zones has a mean value significantly different from each of the Leg 2 zones. However, no such significance was found within each of the 2 groups.

The mean MLD was $85 \pm 27$ dbar during Leg 1 and $220 \pm 49$ dbar during Leg 2 (Figs. 3c,d \& 2). The mixedlayer has a deeper mean value during Leg 2 than Leg 1 , and analysis of these 2 groups revealed that there is a statistically significant difference between the mean MLD of Legs 1 and 2 .

\section{Chl a}

As with the MLD, chl a profiles were analysed according to hydrographic zone and cruise leg. The mean chl a profiles (surface to 500 dbar) for each zone are shown in Fig. 3a. Fig. 3b shows the corresponding potential density profiles. For the sake of clarity, SDs are not shown in these figures. Fig. 3c,d shows the mean chl $a$ and potential density profiles for Leg 1 and Leg $2 \pm \mathrm{SD}$.

Once again it should be noted that $94 \%$ of the stations described by zones IBW1, CIS and SIC were sampled during Leg 1, and all stations described by EGC(A), EGC(P), NIC, RRmw and IBW2 were sampled during Leg 2 .

Visual inspection suggests that variation in the vertical distribution of both chl a and potential density is best described by the demarcation between Legs 1 and 2. No statistical comparison of these profiles was possible. However, in Fig. 3c, it can be seen that the distributions of chl $a$, as described by 1 SD either side of the means, are distinct in approximately the upper 90 dbar, and between 150 and 200 dbar. The surface 90 dbar contain higher concentrations of chl a during Leg 1 than Leg 2, but between 150 and 250 dbar, the opposite is true, with concentrations distinctly higher during Leg 2.

The pattern seen in the chl a profiles does not resolve whether deepening of the mixed layer leads to a change in overall chl a biomass or simply causes a redistribution within the water column. To investigate this, chl a concentrations were integrated over 3 depths corresponding to the approximate range of the mixed layer seen during the cruise. Fig. 2 shows the results of these integrations in relation to the station MLD: individually by Stn $(a, b, c)$, by hydrographic zone $(d, e, f)$ and by cruise leg $(g, h, i)$.

Fig. 2a,d,g shows the chl a biomass integrated between the surface and 50 dbar. Unsurprisingly, the integrated chl a concentrations are lower at stations with greater MLD. This can be partly explained by the 50 dbar integration accounting for a greater proportion of a shallower mixed layer. Leg 1 has a mean MLD of $\sim 86$ dbar (Fig. 2g), thus the 50 dbar integration represents $58 \%$ of the mean mixed layer; Leg 2 on the other hand has a mean MLD of 226 dbar (Fig. 2g), and so the 50 dbar integration covers only $22 \%$ of the mean mixed layer. Fig. 2b,e,h shows the chl a concentrations integrated between the surface and 125 dbar. This covers over $100 \%$ of the Leg 1 mean MLD, and $55 \%$ in the case of Leg 2. As a result of this, the concentrations of chl $a$ are higher during both legs than for the 50 dbar integration. The final 3 panels - Fig. 2c,f,i-cover the surface 325 dbar, which is the maximum MLD of all stations. Because this integration includes the entire mixed layer at all stations, it allows fair comparison of the total levels of chl a biomass in the water column, but only if it is assumed that there is negligible chl a biomass below the mixed layer. This assumption is 


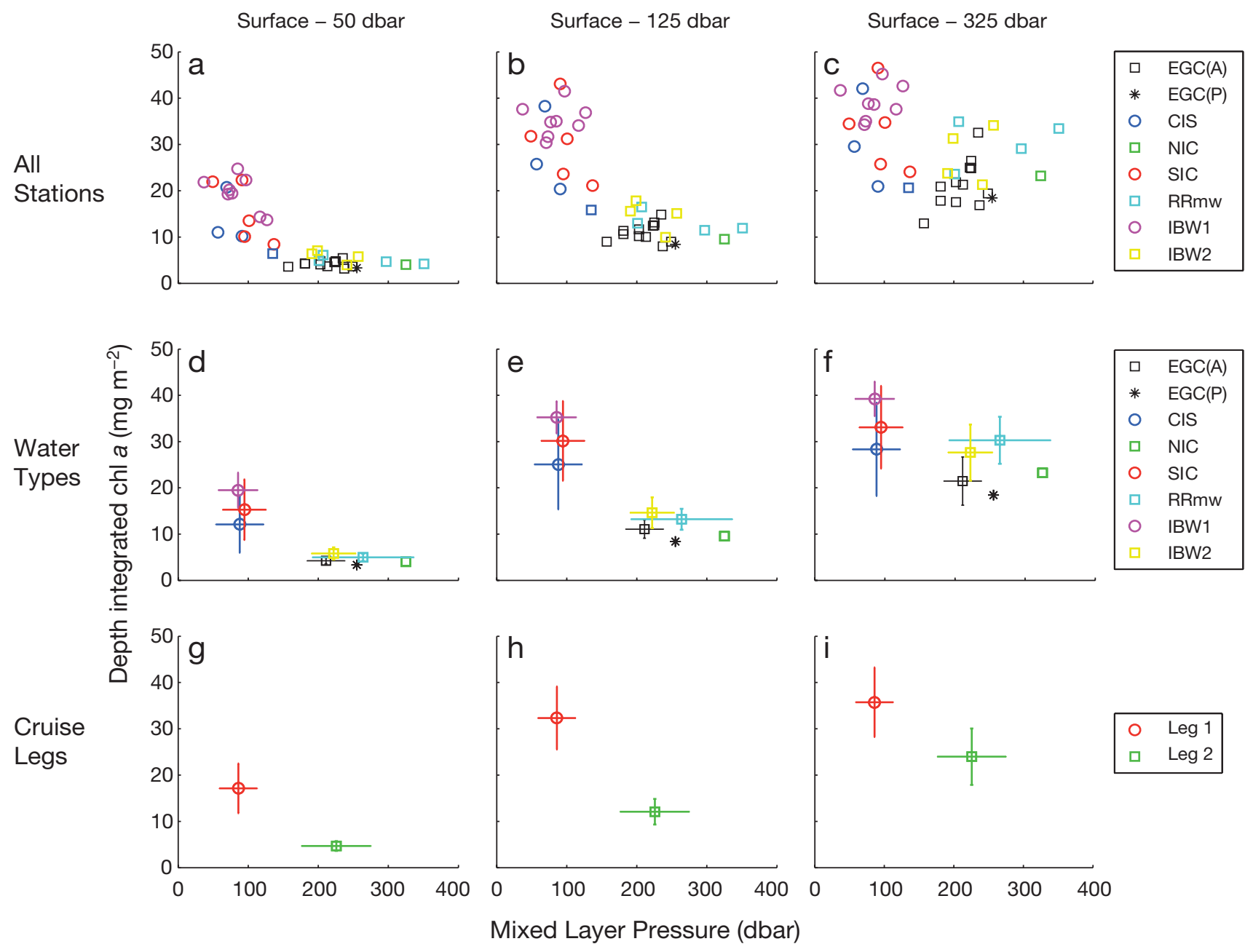

Fig. 2. Depth integrated chlorophyll a $\left(\mathrm{mg} \mathrm{m}^{-2}\right)$ within the surface $(\mathrm{a}, \mathrm{d}, \mathrm{g}) 50$ dbar, $(\mathrm{b}, \mathrm{e}, \mathrm{h}) 125 \mathrm{dbar}$ and $(\mathrm{c}, \mathrm{f}, \mathrm{i}) 325 \mathrm{dbar}, \mathrm{plotted}$ against mixed layer depth. $(\mathrm{a}-\mathrm{c})$ Values at each station, $(\mathrm{d}-\mathrm{f})$ mean values within hydrographic zones $( \pm \mathrm{SD}),(\mathrm{g}-\mathrm{i}) \mathrm{mean}( \pm \mathrm{SD})$ of stations grouped by cruise leg. Circles: Leg 1, Squares: Leg 2 (except EGC[P] zone, shown by asterisk)

supported by the chl a profiles in Fig. 3a,c, where chl a concentrations drop off at the base of the mixed layer. Furthermore, it can be seen that increasing the integration from 125 to 325 dbar has little effect on the resultant chl a concentrations during Leg 1 , because both depths integrate to below most of the mixed layers during this leg. The 3 depths of integration were chosen to reflect the 2 deepest plankton-sampling depths during the cruises, and the deepest observed MLD.

Because of unequal variances, statistical tests could not be performed on the 50 dbar and 125 dbar data. However, for the 325 dbar data, it was revealed that only for the zone pairs EGC(A):SIC and EGC(A):IBW 1 were the differences in chl a concentrations significant. Both of these pairings are between zones sampled entirely during different legs. There were no significant differences between zones sampled during the same cruise leg.
The mean 325 dbar chl a concentrations from each leg were found to be significantly different at the $95 \%$ level. So even when redistributions within the water column are accounted for, the chl a concentrations are significantly lower during Leg 2 , in comparison to Leg 1.

MLD and total chl a can be thought of as manifestations of the general physical (in terms of stratification) and biological oceanography of a region.

\section{Nutrients}

The distribution of nutrients within the surface 500 dbar is shown in Fig. 4. Note that nutrient data were only used from CTD stations. The distributions of nutrients are quite distinct between the 2 cruise legs. Statistical comparisons of the integrated nutri- 

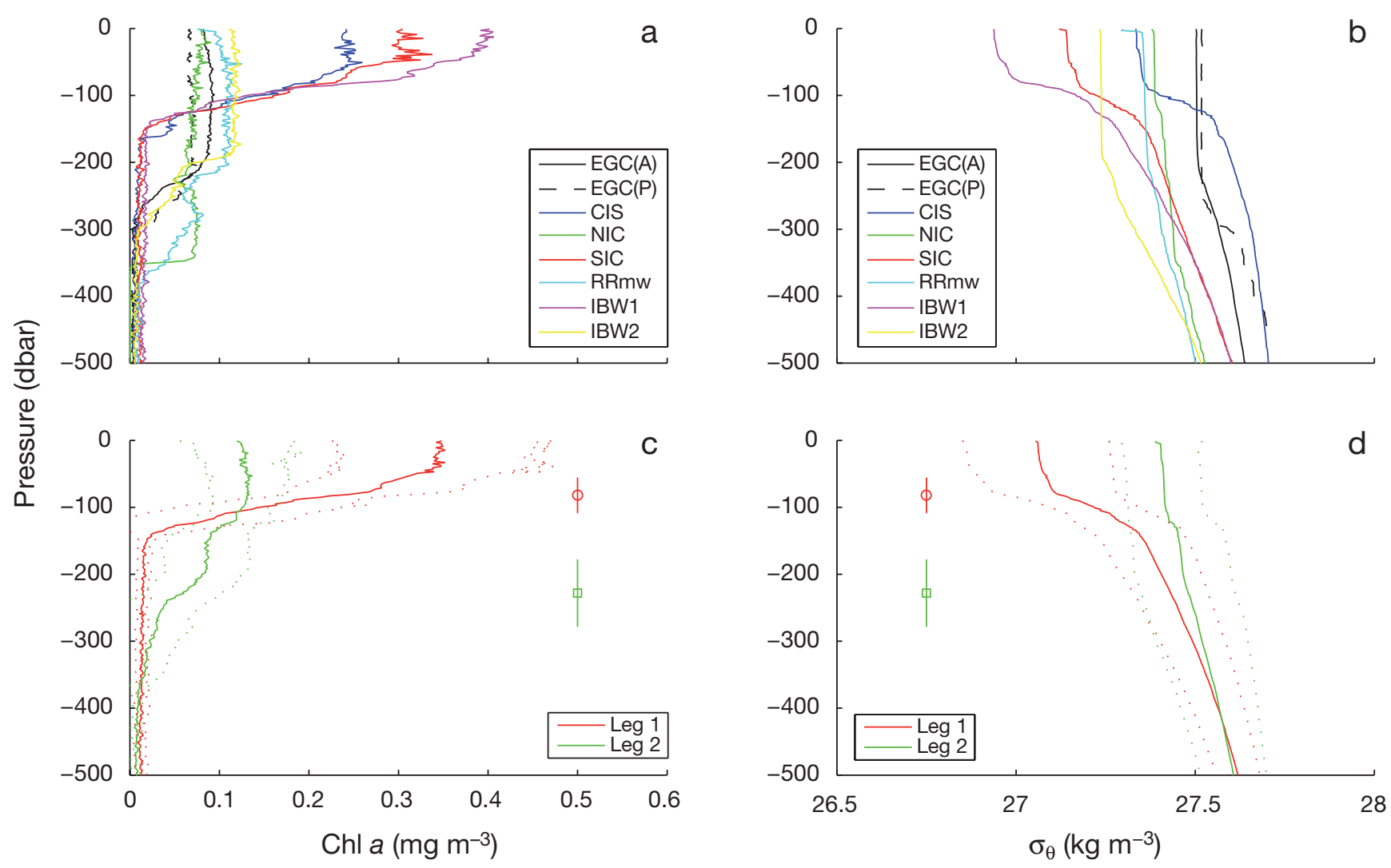

Fig. 3. Mean chl a $\left(\mathrm{mg} \mathrm{m}^{-3}\right)$ and potential density $\left(\sigma_{\theta}, \mathrm{kg} \mathrm{m}^{-3}\right)$ profiles from surface to 500 dbar for $(\mathrm{a}, \mathrm{b})$ all zones and $(\mathrm{c}, \mathrm{d})$ both D258 cruise legs. Dotted lines in panels c and d: \pm 1 SD. Points plotted beside lines (in c,d): mean mixed layer depths for each leg ( \pm 1 SD) (circles: Leg 1; squares: Leg 2)

ent data revealed that in the surface 50 and 125 dbar layers there are significant differences in nitrate, phosphate and silicate from Leg 1 to Leg 2. However, concentrations of these nutrients, integrated over the surface 325 dbar, are not significantly different between Leg 1 and Leg 2. The profiles in Fig. 4 show the expected effect of redistribution in winter, where depleted surface waters were replenished from beneath due to convective mixing. At the end of winter all the profiles will have similar vertical structure and will differ only by the actual surface values because of differences in vertical mixing. Unfortunately, no useful conclusions regarding the overall nutrient distribution can be drawn from these statistical tests, as the 325 dbar integrations will often be corrupted by the high nutrient concentrations below the mixed layer.

\section{Latitude}

Stations sampled during Leg 1 had a mean latitude of $57^{\circ} \mathrm{N}\left(\mathrm{SD}=2.4^{\circ}\right)$; stations sampled during Leg 2 had a mean latitude $62^{\circ} \mathrm{N}\left(\mathrm{SD}=2.5^{\circ}\right)$. A $t$-test revealed these 2 distributions were significantly different. Analysis using simple correlation coefficients (not presented here) revealed that the spatial distribution of stations was more useful in describing variability in the relevant physical and biological oceanography than the temporal distribution. To investigate this further, a range of parameters was plotted with respect to latitude, and the results are presented below.

Fig. 5 shows a selection of vertically integrated biological and physical parameters plotted against latitude. Also included in this figure are corresponding values from Cruise D267 (November 2002). During Cruise D258, significant and strong ( $\mathrm{r}<-0.7)$ negative correlations are seen between latitude and chl a biomass across the 3 depth ranges. Latitude and potential density show similar, but positive correlations across the same depth ranges. Strong negative correlations are seen between latitude and potential temperature across the surface 50 and 125 dbar, with a modest negative correlation across the surface 325 dbar. No correlation was seen between latitude and salinity across any tested depth range. 


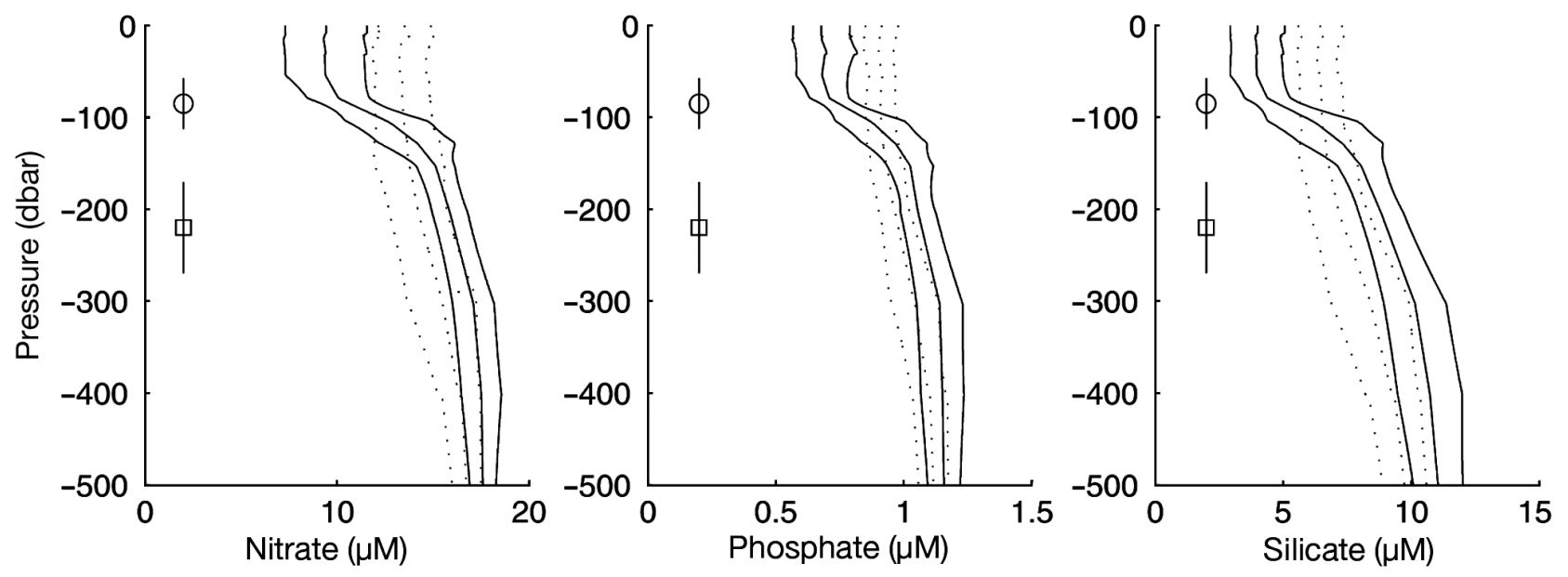

Fig. 4. Nutrient concentration $(\mu \mathrm{M})$ profiles grouped by cruise leg for nitrate, (+ nitrite) phosphate and silicate. Solid lines: Leg 1 ; dotted lines: Leg 2; Middle lines: mean at each depth; outlying lines: \pm 1 SD. Plotted points beside lines in each panel: mean mixed layer depth for Leg 1 (circles) and Leg 2 (squares)

During Cruise D267, a strong negative correlation was seen between latitude and chl a biomass in the surface 50 dbar, which is reduced to a modest negative correlation in the surface 125 dbar. There is no significant correlation over 325 dbar. There is a strong positive correlation between latitude and potential density in the surface 50 and 125 dbar, with a modest positive correlation in the surface 325 dbar. Potential temperature is modestly negatively correlated with latitude over 50 and 125 dbar, with no significant cor-
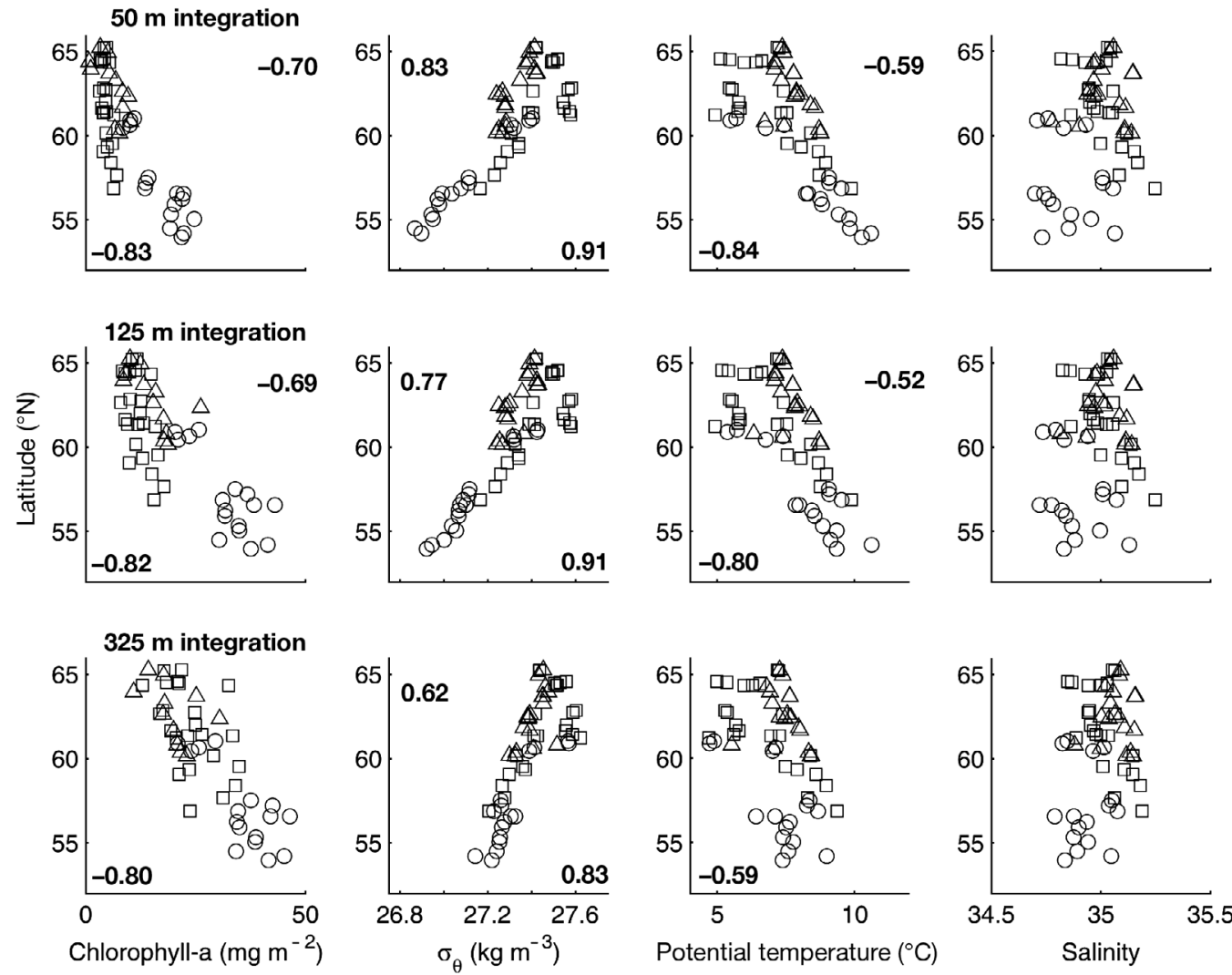

Fig. 5. Integrated chl $a\left(\mathrm{mg} \mathrm{m}^{-2}\right)$, mean potential density $\left(\sigma_{\theta}, \mathrm{kg} \mathrm{m}^{-3}\right)$, mean potential temperature $\left({ }^{\circ} \mathrm{C}\right)$ and mean salinity, between the surface and 50, 125 and $325 \mathrm{~m}$, all plotted against station latitude. Circles and squares: Leg 1 and Leg 2 stations, respectively, for Cruise D258; triangles: D267 stations. Bold numbers: correlation coefficients (r) for D267 (top of panel) and D258 (bottom of panel), where significant 
relation over 325 dbar. Again, there is no significant correlation with salinity at any depth.

Fig. 6 shows 3 meteorological parameters plotted against latitude. The net heat flux shows a modest negative correlation with latitude, with the strongest negative fluxes clearly at the most northerly stations. Similar, negative correlations are seen in the 2 parameters describing the irradiance.

The surface irradiance describes the light at the bottom of the atmosphere, and is thus independent of attenuation by water and particulates in the surface layers. An estimate of the mean light within the mixed layer was made using the attenuation coefficient, $K$. Both of these irradiance variables show a modest negative correlation with latitude, indicating that light may become a more important limiting factor towards the pole.

Fig. 7 illustrates how the MLD exceeds the critical depth in terms of absolute scale (upper panel, where both are plotted on the same axis in relation to latitude) and in relative terms (the $Z_{\mathrm{Cr}}$ :MLD ratio, lower panel). It can be seen that at the higher latitudes the MLD is several hundred meters deeper than the critical depth, yielding $Z_{\mathrm{Cr}}$ :MLD ratios as low as 0.01 .

The relative dominance of different phytoplankton groups within the surface waters shows some significant correlations with latitude (Fig. 8). The carbon biomass of 3 groups is shown as a percentage of the total phytoplankton carbon biomass. Of the significant patterns seen, diatoms decrease as a percentage towards the north at both 10 and $50 \mathrm{~m}$, while flagellates are seen to increase as a percentage at the same depths. Picoplankton significantly (but weakly) increase as a percentage towards the north at $50 \mathrm{~m}$, but no significant pattern was seen at $10 \mathrm{~m}$ within this group.

\section{DISCUSSION}

The data collected during Marine Productivity Cruises D258 and D267 provide a multidisciplinary synopsis of late autumn and winter conditions in the Irminger Sea, describing a range of important physical, chemical and biological parameters. Analysis of the results presented in this paper allows a description of the mechanisms by which abiotic factors dictate the perhaps unexpectedly high chl a concentrations seen in a high latitude ocean during the winter months. A short summary of these results is presented below.

During the 2 autumn/winter cruises, the MLD was seen to increase with latitude, apparently caused by convective overturning as a result of thermally-driven buoyancy fluxes. These fluxes also increased towards the pole. In combination with reduced irradiance at higher latitudes, this deepening of the mixed layer was seen to cause lower mean irradiances available to phytoplankton within that layer.

As the MLD increased and light was reduced with latitude, mean $\mathrm{chl}$ a concentrations within the mixed layer declined. Furthermore, chl a concentrations integrated across the upper $325 \mathrm{dbar}$ (the maximum extent of the mixed layer observed in this study) also decreased. This suggests that while mean phytoplankton concentrations fell as the existing population was redistributed over the deepening mixed layer, the effect was augmented as the overall biomass was reduced by light limitation at high latitudes. This light limitation hypothesis is supported by the consistently high concentrations of nutrients observed throughout both surveys.

Despite the extremely low PAR seen at higher latitudes during the winter months, the chl a concentrations within the mixed layer never fell below approxi-
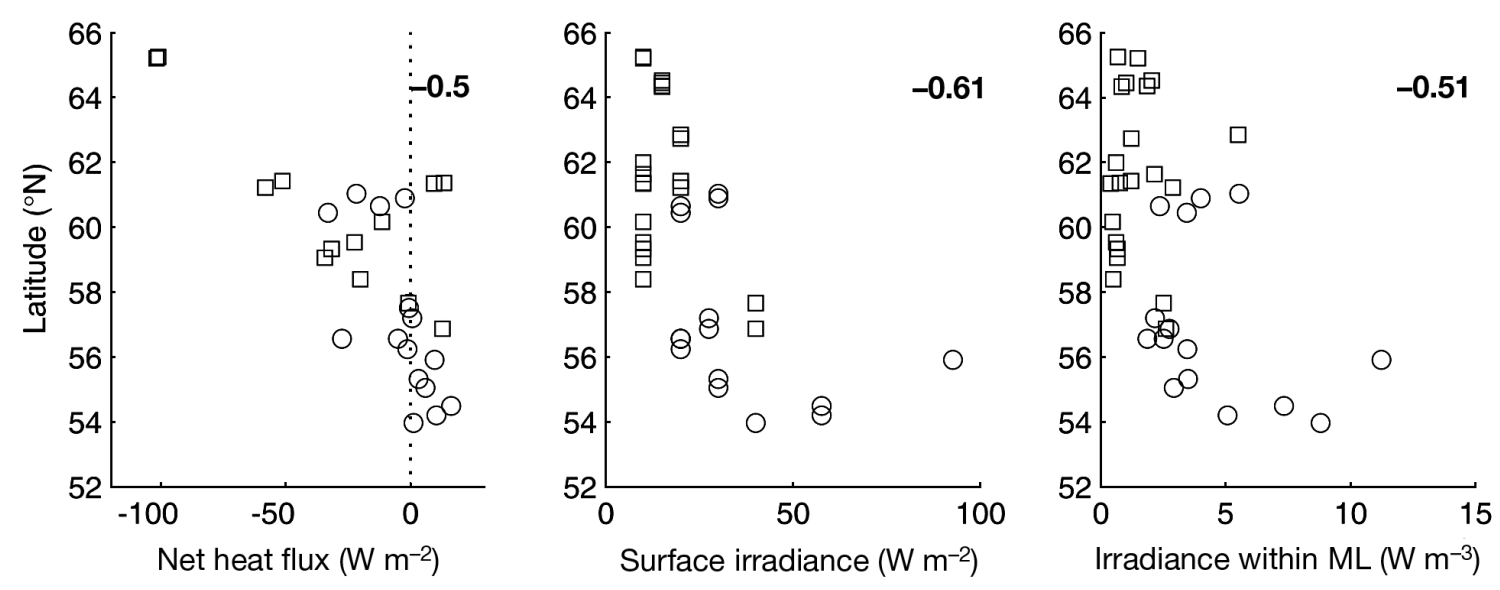

Fig. 6. Individual station values for net heat flux, irradiance at the surface and mean irradiance within the mixed layer (ML), all plotted against latitude. Circles and squares: D258 Leg 1 and Leg 2 stations, respectively; dotted black line: zero net heat flux; bold numbers: correlation coefficients (r), where significant 


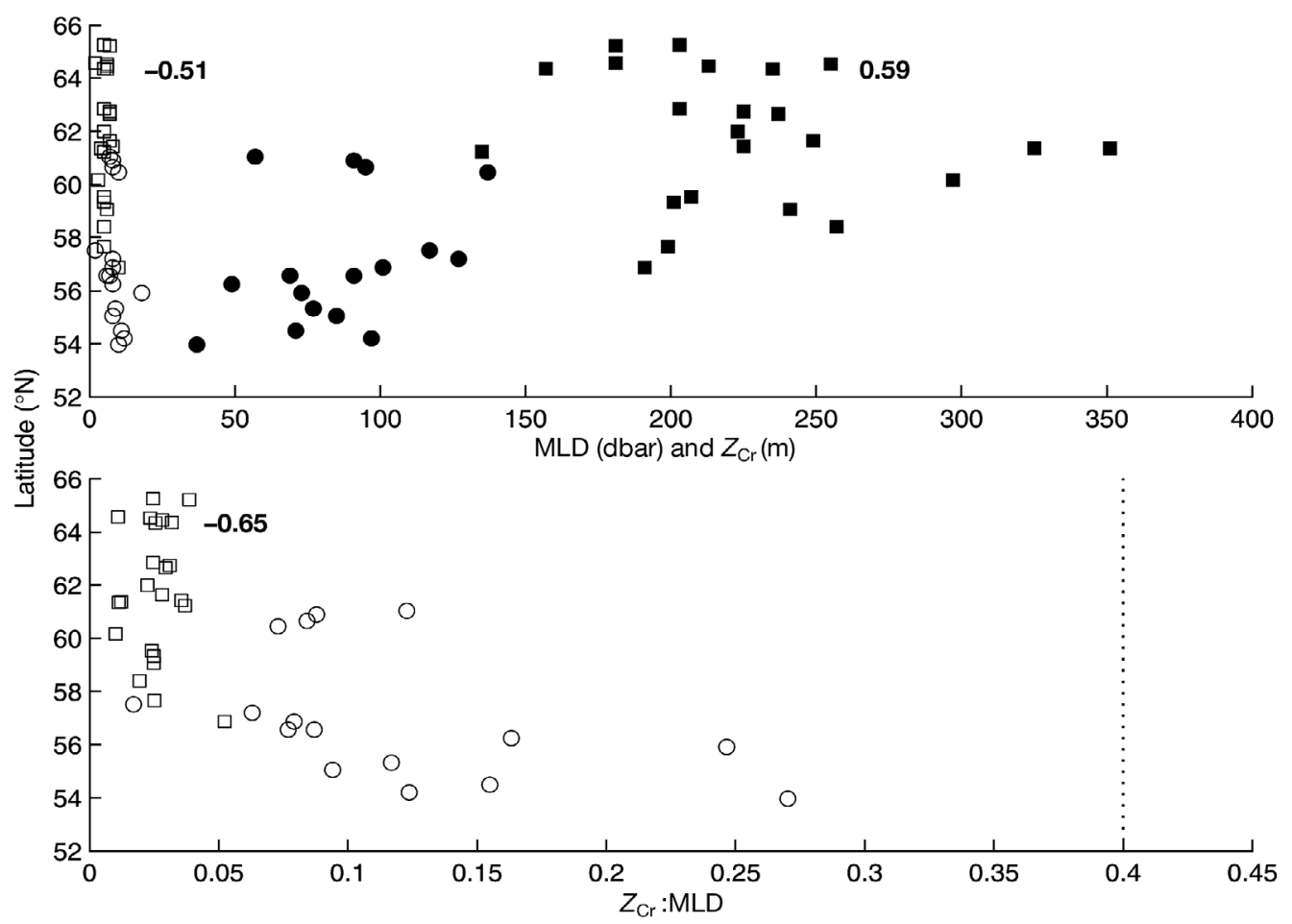

Fig. 7. Individual station values for (upper panel) mixed layer depth (MLD) and critical depth $\left(Z_{\mathrm{Cr}}\right)$ and (lower panel) $Z_{\mathrm{Cr}}: \mathrm{MLD}$ ratio, all plotted against latitude. Closed symbols: MLD, open symbols: $Z_{\text {Cri }}$ circles and squares: D258 Leg 1 and Leg 2 stations, respectively; dotted line: $Z_{\mathrm{Cr}}$ :MLD value of 0.4 ; bold numbers: correlation coefficients $(\mathrm{r})$, where significant
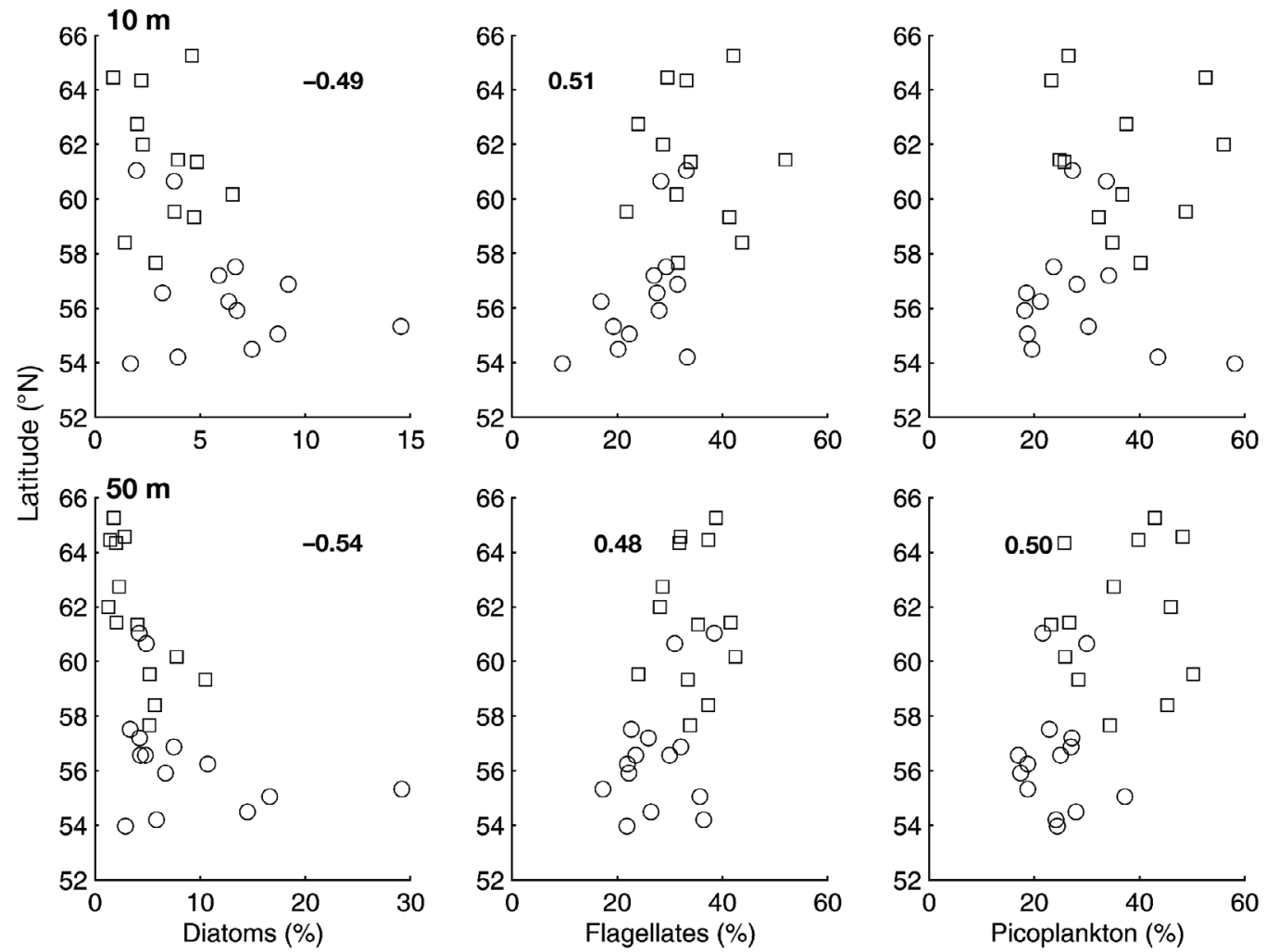

Fig. 8. Phytoplankton assemblages from Cruise D258 for diatoms, flagellates and picoplankton, as a percentage of total carbon biomass, at 10 and $50 \mathrm{~m}$. Circles: Leg 1 stations, squares: Leg 2 stations; bold numbers in graphs: correlation coefficients (r), where significant (includes significant but weak correlations) 
mately $0.1 \mathrm{mg} \mathrm{m}^{-3}$. This baseline value was ubiquitous and constant across the entire mixed layer during periods of strong light limitation, regardless of the depth of the mixed layer. Conversely, chl a concentrations below the mixed layer were always close to the detection limit of $0.01 \mathrm{mg} \mathrm{m}^{-3}$.

In the following sections, an attempt is made to answer 2 questions: (1) How is spatial and temporal variability in mean chl a concentrations (as a proxy for phytoplankton biomass) controlled?; and (2) Why do these concentrations not fall to zero under extremely light-limited winter conditions? The maintenance of the over-wintering stock is an important problem, because it is this stock that provides the seed population for the spring bloom (Backhaus et al. 1999). The spring bloom occurs every year in the North Atlantic, to a greater or lesser extent, and the initial growth rate of the bloom has been shown to be dependent on the pre-bloom phytoplankton composition (Waniek 2003). The magnitude and duration of the spring bloom is an important factor in the global carbon and nutrient cycles and has been a perennial subject of interest for oceanographers for over 70 years (Gran \& Braarud 1935, Sverdrup 1953, Menzel \& Ryther 1961, Fasham 1995, Follows \& Dutkiewicz 2001, Waniek 2003, Waniek et al. 2005).

It has been noted that during the seasonal bloom in the subpolar gyre, chl a concentrations decrease with convective mixing and increase with stratification (Waniek 2003), while in the subtropical gyre chlorophyll concentrations increase with convective mixing (Menzel \& Ryther 1961). Follows \& Dutkiewicz (2001) hypothetically split the North Atlantic into 2 distinct regions, according to the ratio of the critical depth to the MLD, $Z_{\mathrm{CR}}$ :MLD $\left(H_{c}: H_{m}\right.$ in Follows \& Dutkiewicz 2001). The subpolar gyre is defined by $Z_{\mathrm{CR}}$ :MLD ratios of less than 0.4 , where the MLD is much greater than the critical depth, and production is generally limited by reduced light availability with increased mixing rather than by nutrient limitation upon prolonged stratification. Fig. 7 shows that the $Z_{\mathrm{CR}}$ :MLD ratios during Cruise D258, unsurprisingly, lie firmly within the subpolar regime. Different estimations of the critical depth (Siegel et al. 2002) and MLD (Thomson \& Fine 2003) were used in this study, but the underlying principle is the same. This suggests that light, as a function of latitude and depth of mixing, is the most important limiting factor in the Irminger Sea, and this is supported by observed nutrient concentrations that are well above limiting values (Sambrotto et al. 1993, Fasham 1995).

During both cruises analysed in this study, atmospheric conditions, hydrographic conditions and chl a biomass are all strongly correlated with latitude and moderately correlated with time. It seems that as the cruises move forward in time and northward in space, the meteorological forcing increases, leading to deepening of the mixed layer and shoaling of the critical depth. This ultimately leads to a deterioration of the phytoplankton growth conditions and a reduced biomass. The shift from moderate-late autumn biomass conditions to low-early winter biomass conditions is controlled in this way. Specifically, towards the Arctic Circle, stronger and colder winds lead to greater heat fluxes and buoyancy losses from the surface waters, causing a deepening of the mixed layer. Phytoplankton are thus mixed further away from the surface, reducing the amount of light they receive. This process is augmented by the changing irradiance, which also falls towards the pole; and production is increasingly limited towards the winter baseline concentration of $0.1 \mathrm{mg} \mathrm{m}^{-3}$.

In summary of the underlying causes of spatial and temporal variability, the shift from autumn to winter and from south to north is accompanied by increasing light limitation and reduced chl a concentrations, in agreement with previously published work (Sverdrup 1953, Menzel \& Ryther 1961, Follows \& Dutkiewicz 2001). What the conventional theories cannot explain, however, is why the mean chl a concentrations in the mixed layer never fall below the baseline level seen in this study and also in Backhaus et al. (2003).

During Leg 2 of D258, the $Z_{\mathrm{CR}}$ :MLD ratio falls to 0.01 (Stn 14287: $Z_{\mathrm{CR}}=3 \mathrm{~m}, \mathrm{MLD}=297$ dbar) (Fig. 7), with the daily mean irradiance in the mixed layer falling to $0.4 \mathrm{~W}$ $\mathrm{m}^{-2}$ (Fig. 6). Yet the mean chl a biomass in the mixed layer remains about $0.1 \mathrm{mg} \mathrm{m}^{-3}$, never falling to the detection-limit concentrations consistently seen below the mixed layer. Furthermore, in the underway data, the minimum surface chl a value seen during the entire cruise was $0.09 \mathrm{mg} \mathrm{m}^{-3}$. So, despite the extremely low irradiances in the mixed layer seen during most of Cruise D258 and all of Cruise D267, it appears that there is always a baseline phytoplankton population within the surface mixed layer. This supports the observations of Backhaus et al. (2003) that a winter population is maintained even under conditions of very deep mixing. Complimentary evidence has been presented here suggesting that while chl a concentrations do fall with increased MLD during the autumn regime, once the conditions are characteristic of the winter regime, mean concentrations remain constant at around $0.1 \mathrm{mg} \mathrm{m}^{-3}$ across the entire mixed layer (Fig. 3).

Assuming that the community loss processes described earlier are ongoing in winter, it is surprising that the biomass concentrations can be maintained in such low light conditions. To realign this imbalance with conventional theories, it will be necessary to either find a greater capability for production, given the strong light-limitation of growth, or to reduce the 
community loss processes. By re-evaluating these qualities, it may be possible for estimates of the critical depth to be revised downwards (deeper), thus allowing for an explanation of the sustained biomass.

Looking at the first of these 2 approaches, Backhaus et al. (2003) sought extra primary production within the winter mixed layer and described how convective overturning may provide a mechanism by which phytoplankton are exposed to mean irradiances much higher than was previously estimated. Through regular convective cycling, individual phytoplankton are repeatedly moved in and out of the euphotic zone on timescales on the order of $1 \mathrm{~d}$. Thus phytoplankton within the winter mixed layer can be said to occupy a 'virtual euphotic zone', where daily light intensity may be averaged over the entire depth of the mixed layer because of the redistribution of phytoplankton by convection.

Backhaus et al. (2003) suggested that constant convective redistribution of individual phytoplankton eliminates the importance of the Sverdrup (1953) compensation depth, which is defined as the point where production of biomass equals losses by respiration, sinking and mortality at that particular depth. However, the compensation depth is only relevant to local primary production/loss balance at an individual depth. The more useful parameter is critical depth, defined as the depth where daily community loss processes (to use Siegel et al.'s (2002) term) and primary production balance when integrated between that depth and the surface.

It is true that the original theory reported by Sverdrup (1953) may not account for all the primary production in the mixed layer, as the theory ignores any primary production between the critical depth and a deeper MLD, but it can be shown that this is not important, because the theory also ignores the greater community loss processes across the same depths.

The depth profile of irradiance decreases exponentially with depth, and it is assumed that primary production is linearly related to irradiance in the predominantly light-limited conditions. Thus, primary production also decreases exponentially with depth. The community loss processes, however, remain constant with depth. At the compensation depth, primary production exactly balances losses, and below this, the local budget for net community production can only be negative.

During the winter, the MLD is deeper than the critical depth, almost by definition. What Backhaus et al. (2003) do with the virtual mixed layer is to increase the integration from the critical depth to the MLD across which range the local balance between primary production and community loss processes is always negative. This may actually be a more accurate approximation of the production vs. loss balance, but it does not find the extra production needed to answer the question of how a baseline of phytoplankton population is maintained. This is not to say that convection is not important in redistributing the phytoplankton within the mixed layer. In fact, over such depths of mixing that are reported here, convective motions are the primary cause of the vertical homogeneity that is seen. Convection does not, however, allow for any extra production to be found that is not already accounted for by Sverdrup (1953).

Convection may yet play a role in maintaining higher than expected phytoplankton biomass, because of the upward vertical motions implied by the conservation of mass. As dense water sinks from the surface, less dense water must also rise from deep in the mixed layer to replace it. These upward vertical motions may play a role in maintaining the phytoplankton in the mixed layer for a longer period, and thus reduce the loss terms (Backhaus et al. 1999).

Instead of looking for extra production, the second approach is to see if losses by respiration, natural (nongrazing) mortality, herbivory and sinking across the base of the mixed layer are erroneous, in which case the critical depth could also be wrong.

In our study, the community loss processes are derived from an assumed community compensation irradiance of $3.9 \mathrm{~W} \mathrm{~m}^{-2}$. This was calculated from Siegel et al. (2002) as the mean value between $50^{\circ}$ and $70^{\circ} \mathrm{N}$, based on spring and summer data. Because of the high variability in growth conditions during the seasonal cycle, it is most likely invalid to assume that this value is constant throughout the year, so a reassessment of the loss processes seems sensible. Firstly, sinking losses are reassessed with respect to convection.

Convection involves an overturning of dense water in narrow plumes with vertical scales of the order of 100 to $1000 \mathrm{~m}$ and horizontal scales of a few $\mathrm{km}$. The narrow downward flux of water is accompanied by a more diffuse upwelling within a convection plume, which is required to satisfy conservation of mass (Marshall \& Schott 1999). This cyclic motion may serve to trap particulate matter, including phytoplankton, within the mixed layer for longer (Backhaus et al. 1999, Williams \& Follows 2003).

Huisman et al. $(1999,2002)$, examined the role of turbulence within the mixed layer using a turbulent diffusion model, and thus they suggested that phytoplankton with relatively low sinking velocities may be maintained longer above the critical depth under conditions of moderate turbulent mixing (Huisman et al. 2002). The speed at which phytoplankton sink in the water column is dependent on their size, shape, buoyancy and motility (Smayda 1970). For phytoplankton with greater sinking velocities, sinking exceeds the effects of turbulent mixing earlier, and thus the win- 
dow of intermediate turbulence where populations can be maintained is reduced (Huisman et al. 2002).

The modelling study of Huisman et al. (2002) shows that phytoplankton with relatively low sinking velocities may be maintained above the critical depth under conditions of moderate turbulent mixing. While the convective regime of the Irminger Sea in winter will be highly turbulent, it seems that if there can be competition between sinking and turbulence (Huisman et al. 2002), there may also be competition between sinking and convection at the base of the mixed layer. If this is the case, phytoplankton with lesser sinking velocities will be maintained for longer periods in the mixed layer by tight coupling to convective motions of the water (Backhaus et al. 1999). This means that slower sinking phytoplankton will have a deeper critical depth, and thus they will gain a selective advantage in the severely light-limited mixed layer during the winter (Huisman 1999).

Fig. 8 shows observed phytoplankton biomasses by group as a percentage of the total phytoplankton biomass. Picoplankton biomass percentages are seen to significantly increase with latitude at $50 \mathrm{~m}$ depth (in line with the postulated move from autumn to winter), while diatoms show the opposite pattern at 10 and $50 \mathrm{~m}$. Picoplankton are by definition very small (0.2 to $2.0 \mu \mathrm{m}$, Nybakken 1997), and according to Stoke's law, they are less prone to sinking than larger groups (Gardner 1997). Diatoms are characterised by a large and fairly dense silica-based structure, making them prone to sinking (Billet et al. 1983). The apparent selection of picoplankton in favour of diatoms under winter conditions seems to support the hypothesis that they will be maintained in the water column for longer periods, because they are more closely coupled to (mostly) convective motions of the water column (Huisman et al. 2002). Because the export of the smaller phytoplankton is reduced, the community loss terms are also diminished, and thus the critical depth can also be revised downwards.

It is important to note that even though diatoms fall as a percentage of the total phytoplankton biomass, this is not evidence that they are directly disadvantaged by convection; it is simply that they are favoured less than the flagellates or picoplankton. The typical water velocities in a convective regime are in the order of 1 to $10 \mathrm{~cm} \mathrm{~s}^{-1}$, while a relatively fast phytoplanktonsinking rate of $200 \mathrm{~m} \mathrm{~d}^{-1}$ corresponds to only $0.23 \mathrm{~cm}$ $\mathrm{s}^{-1}$. 'With this large difference between convection dynamics and sinking rates, it is very likely that the vertical motions induced by convection will ...override the effect of sinking' (Backhaus et al. 1999). This includes diatoms.

Diatoms are typically the first species to bloom in the Irminger Sea (Wassman et al. 1999), and thus if they were not present in the winter population it would raise a difficult question as to where they came from. However, it seems that even the fast sinking diatoms are maintained by convection to some extent, as even during Leg 2 of Cruise D258, they account for $3 \%$ of the phytoplankton biomass at $10 \mathrm{~m}$, and $4 \%$ at $50 \mathrm{~m}$. This is compared to 6 and $9 \%$ at the same depths during Leg 1.

Another mechanism by which phytoplankton maintain themselves within the mixed layer is through motility (Sverdrup 1953). If this is true, then the motile groups should be favoured in winter conditions over non-motile, fast-sinking groups like the diatoms. It has already been shown that diatoms decrease as a fraction of the total biomass in winter, and it can be seen in Fig. 8 that the motile heterotrophic and photosynthetic dinoflagellates show a significant positive correlation with latitude at 10 and $50 \mathrm{~m}$ depths. Again this is indirect evidence that species which are maintained within the mixed layer for longer periods have an advantage over those species that are not.

If the observed patterns in the phytoplankton communities represent a genuine selection process, then it is indirect evidence that one of the ways by which an over-wintering stock is maintained in the mixed layer is by reduction of the community loss through reduced detrainment from the mixed layer. This is a similar conclusion to that of Backhaus et al. (2003), but the mechanism by which $Z_{\mathrm{Cr}}$ is revised is different, and $Z_{\mathrm{Cr}}$ is not fixed to the base of the mixed layer.

Community loss processes also include grazing pressure from zooplankton (Siegel et al. 2002). Modelling studies have shown that in a deeply mixed, light-limited mixed layer in winter, phytoplankton production is very low, and herbivorous zooplankton populations can not maintain concentrations as high as during the summer months (Evans \& Parslow 1989, Fasham 1995). Copepod species in the northern North Atlantic have also been shown to spend the winter deep in the water column in a dormant, non-feeding state (Hirsche 1983, Bathman et al. 1990). Furthermore, in a sparsely populated ocean, the encounter rate between phytoplankton and zooplankton will be less than in a densely populated ocean, and so grazing will be further reduced in winter. It has also been suggested that while moderate levels of turbulence may enhance encounter rates between plankton (and hence grazing pressure), strong turbulence, as might be seen during a convective regime, could have a detrimental effect on the feeding currents used by zooplankton to ingest phytoplankton (Saiz et al. 1992).

At the time of writing, zooplankton data were unavailable from either cruise. It has therefore been impossible to draw any firm conclusions regarding the role of herbivory in the observed ecosystem. However, 
if some of the ideas presented here are to be examined further, i.e. a reappraisal of community loss processes, then analysis of such data, in the context of the seasonal cycle, would be the logical next step.

Further to this, use of a biological-physical model that utilises discrete functional phytoplankton groups would allow for a useful test of the hypothesis that certain groups gain a selective advantage during winter by means of a low sinking rate. How this relates to the ubiquitous $0.1 \mathrm{mg} \mathrm{m}^{-3}$ baseline chl a concentration should also be investigated.

Acknowledgements. The authors thank the crew of the RSS 'Discovery' and the scientists involved in the Marine Productivity Thematic Programme cruises, funded by the Natural Environment Research Council (NERC, UK), a contribution to UK GLOBEC. The authors thank the 3 referees for their valuable comments on the submitted manuscript and for their help to clarify and improve the manuscript.

\section{LITERATURE CITED}

Backhaus JO, Wehde H, Hegseth EN, Kampf J (1999) 'Phytoconvection': on the role of oceanic convection in primary production. Mar Ecol Prog Ser 189:77-92

Backhaus JO, Hegseth EN, Wehde H, Irigoien X, Hatten $\mathrm{K}$, Logemann K (2003) Convection and primary production in winter. Mar Ecol Prog Ser 251:1-14

Bacon S (2002) A freshwater jet on the east Greenland shelf. J Geophys Res 107, doi: 10.1029/2001JC000935, 002002

Bacon S, Gould WJ, Jia Y (2003) Open-ocean convection in the Irminger Sea. Geophys Res Lett 30, doi: 10.1029/2002GL016271

Barton AD, Greene CH, Monger BC, Pershing AJ (2003) The Continuous Plankton Recorder survey and the North Atlantic Oscillation: interannual- to multidecadal-scale patterns of phytoplankton variability in the North Atlantic Ocean. Prog Oceanogr 58:337-358

Bathman UV, Noji TT, von Bodungen B (1990) Copepod grazing potential in late winter in the Norwegian Sea - a factor in the control of spring phytoplankton growth. Mar Ecol Prog Ser 60:225-233

Billet DSM, Lampitt RS, Rice AL, Mantoura RFC (1983) Seasonal sedimentation of phytoplankton to the deep sea benthos. Nature 302:520-522

Dutkiewicz S, Follows M, Marshall J, Gregg WM (2001) Interannual variability of phytoplankton abundances in the North Atlantic. Deep-Sea Res II 48:2323-2344

Eppley RW, Read F, Strickland J (1970) Ecology of the plankton of La Jolla, California, in the period April through September 1967. Bull Scripps Inst Oceanogr Univ Calif 17:33-42

Evans GT, Parslow JS (1985) A model of annual plankton cycles. Biol Oceanogr 3:327-347

Fasham MJR (1995) Variations in the seasonal cycle of biological production in subarctic oceans: A model sensitivity analysis. Deep-Sea Res I 42:1111-1149

Follows M, Dutkiewicz S (2001) Meteorological modulation of the North Atlantic spring bloom. Deep-Sea Res II 49: 321-344

Gačić M, Civitarese G, Miserocchi S, Cardin V, Crise A, Mauri E (2002) The open-ocean convection in the Southern Adriatic: a controlling mechanism of the spring phytoplankton bloom. Cont Shelf Res 22:1897-1908
Gardner WD (1997) The flux of particles to the deep sea: methods, measurements, and mechanisms. Oceanography 10:116-121

Gran HH, Braarud T (1935) A quantitative study of the phytoplankton in the Bay of Fundy and the Gulf of Maine. J Biol Board Can 1:279-467

Hirche HJ (1983) Overwintering of Calanus finmarchicus and Calanus helgolandicus. Mar Ecol Prog Ser 11:281-290

Holliday NP, Waniek J, Davidson R, Wilson D, Brown L, Sanders R, Pollard RT, Allen JT (2006) Large-scale physical controls on phytoplankton growth in the Irminger Sea. Part I. Hydrographic zones, mixing and stratification. J Mar Syst 59(3-4):201-218, doi: 10.1016/j.jmarsys.2005. 10.004

Holligan PM, Harris RP, Newell RC, Harbour DC and 5 others (1984) Vertical distribution and partitioning of organic carbon in mixed, frontal and stratified waters of the English Channel. Mar Ecol Prog Ser 14:111-127

Huisman J, van Oostveen P, Weissing FJ (1999) Critical depth and critical turbulence: two different mechanisms for the development of phytoplankton blooms. Limnol Oceanogr 44:1781-1787

Huisman J, Arrayas M, Ebert U, Sommeijer B (2002) How do sinking phytoplankton species manage to persist? Am Nat 159:245-254

Jeffrey SW, Humphrey GF (1975) New spectrophotometric equation for determining chlorophyll a, b, c1 and c2. Biochem Physiol Pflanz 167:194-204

Jerlov NG (1968) Optical oceanography. Elsevier, Amsterdam

Kirk JTO (1994) Light and photosynthesis in aquatic ecosystems. Cambridge University Press, Cambridge

Kirkwood DC (1995) The SanPlus segmented flow Autoanalyser and its applications. Scalar Analytical BV Publications, Breda

Kovala PE, Larrance JD (1966) Comparison of phytoplankton cell numbers, cell volume, cell surface and plasma volume, per metre, from microscopic counts. Univ Wash Spec Rep 36:1-21

Lavender KL, Davis RE, Owens WB (2000) Mid-depth recirculation observed in the interior Labrador and Irminger seas by direct velocity measurements. Nature 407:66-69

Longhurst A, Sathyendranath S, Platt T, Caverhill C (1995) An estimate of global primary production in the ocean from satellite radiometer data. J Plankton Res 17:1245-1271

Marshall J, Schott F (1999) Open ocean convection: observations, theory and models. Rev Geophys 37:1-64

Menzel DW, Ryther JH (1961) Annual variations in primary production of the Sargasso Sea off Bermuda. Deep-Sea Res 7:282-288

Moore GWK (2003) Gale force winds over the Irminger Sea to the east of Cape Farewell, Greenland. Geophys Res Lett 30:1894

Morel A (1988) Optical modeling of the upper ocean in relation to its biogenous matter content (Case I Waters). J Geophys Res 93:10749-10768

Nybakken JW (1997) Marine biology: an ecological approach, 4th edn. Addison-Wesley Educational Publishers, Reading

Pickart RS, Straneo F, Moore GWK (2002) Is Labrador sea water formed in the Irminger Basin? Deep-Sea Res I 50: $23-52$

Pickart RS, Spall MA, Ribergaard MH, Moore GWK, Milliff RF (2003) Deep convection in the Irminger Sea forced by the Greenland tip jet. Nature 424:152-156

Pollard RT, Hay SJ (2002) RRS Discovery cruise 258. Biophysical studies of zooplankton dynamics in the northern North Atlantic: winter, 1 Nov-18 Dec 2001, Natural Environnment Research Council, Swindon. Available at: 
www.bodc.ac.uk/projects/uk/marprod/cruise_programme/ documents/d258cruisereport.pdf

Pollard RT, Read JF, Holliday NP, Leach H (2004) Water masses and circulation pathways through the Iceland Basin during Vivaldi 1996. J Geophys Res 109, doi: 10.1029/2003JC002067, 002004

Read JF (2001) CONVEX-91: water masses and circulation of the Northeast Atlantic subpolar gyre. Prog Oceanogr 48: 461-510

Reverdin G, Niiler PP, Valdimarsson H (2003) North Atlantic Ocean surface currents. J Geophys Res 108, doi: 10.1029/2001JC001020, 002003

Saiz E, Alcaraz M, Paffenhoffer GA (1992) Effect of smallscale turbulence on feeding rate and gross growth efficiency of three Arcatia species. J Plankton Res 14: 1085-1097

Sambrotto RN, Martin JH, Broenkow WW, Carlson C, Fitzwater SE (1993) Nitrate utilization in surface waters of the Iceland Basin during spring and summer of 1989. DeepSea Res II 40:441-458

Sanders R, Jickels T (2000) Total organic nutrients in Drake Passage. Deep-Sea Res I 47:997-1014

Santoleri R, Banzon V, Marullo S, Napolitano E, D'Ortenzio F, Evans R (2003) Year-to-year variability of the phytoplankton bloom in the southern Adriatic Sea (1998-2000): sea-viewing wide field-of-view sensor observations and modeling study. J Geophys Res 108, doi: 10.1029/ 2002JC001636

Editorial responsibility: Otto Kinne (Editor-in-Chief), Oldendorf/Luhe, Germany
Siegel DA, Doney SC, Yoder JA (2002) The North Atlantic spring phytoplankton bloom and Sverdrup's critical depth hypothesis. Science 296:730-732

Smayda TJ (1970) The suspension and sinking of phytoplankton in the sea. Oceanogr Mar Biol Annu Rev 8:353-414

Sverdrup HU (1953) On conditions for the vernal blooming of phytoplankton. J Cons Int Explor Mer 18:287-295

Thomas AC, Townsend DW, Weatherbee R (2003) Satellitemeasured phytoplankton variability in the Gulf of Maine. Cont Shelf Res 23:971-989

Thomson RE, Fine IV (2003) Estimating mixed layer depth from oceanic profile data. J Atmos Ocean Technol 20: $319-329$

Waniek JJ (2003) The role of physical forcing in initiation of spring blooms in the northeast Atlantic. J Mar Syst 39: $57-82$

Waniek JJ, Holliday PN, Davidson R, Brown L, Henson S, Pollard R (2005) Freshwater control of the onset and species composition of the Greenland shelf spring bloom. Mar Ecol Prog Ser 288:45-57

Wassman P, Ratkowa T, Andreassen I, Vernet M, Petersen G, Rey F (1999) Spring bloom development in the marginal ice zone and the central Barents Sea. PSZN I: Mar Ecol 20(3-4):321-346

Williams RG, Follows MJ (eds) (2003) Physical transport of nutrients and the maintenance of biological production. In: Fasham M (ed) Ocean biogeochemistry: the role of the ocean carbon cycle in global change. Springer, Berlin

Submitted: August 11, 2005; Accepted: June 19, 2006 Proofs received from author(s): February 1, 2007 